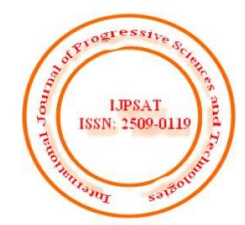

\title{
The Rhetorical Structure of the Lubuklinggau Mayor's Speech in Building Community Trust
}

\author{
Noermanzah $^{1}$, Selbi Wahyuni ${ }^{2}$, Tri Astuti ${ }^{3}$, Dian Eka Chandra Wardhana ${ }^{4}$, Syafryadin $^{5}$ \\ ${ }^{1}$ Departement of Language and Arts Education, University of Bengkulu, Indonesia \\ ${ }^{2}$ Departement of Language and Arts Education, STKIP PGRI Lubuklinggau, Indonesia \\ ${ }^{3}$ Departement of Language and Arts Education, STKIP PGRI Lubuklinggau, Indonesia \\ ${ }^{4}$ Departement of Language and Arts Education, University of Bengkulu, Indonesia \\ ${ }^{5}$ Postgraduate Program of English Education, University of Bengkulu, Indonesia \\ $((c))$ EY
}

\begin{abstract}
This study aims to describe the rhetorical structure of the Lubuklinggau Mayor's speech in building public trust. The research method uses the content analysis method. Data collection techniques using documentation techniques in the form of video recordings of Lubuklinggau Mayor's speeches. Text data analyzed were taken from speeches delivered by the Mayor of Lubuklinggau. Text data were analyzed based on the generic structure of narrative texts by Labov and the rhetorical structure theory developed by Mann and Thompson. The results of the study show that each text has an abstract part, orientation, problem complexity, resolution, and data and fact based codes so as to build public trust. The interesting thing from the speech by the Mayor of Lubuklinggau is that the delivery of speech is dominated by the Palembang regional language and begins with small talk that implies a specific purpose and is accompanied by expressions that contain humor and appreciation.
\end{abstract}

Keywords - rhetorical structure, speeches, mayors, public trust

\section{INTRODUCTION}

In the millennial era, the competencies required by the language learners are creative, critical thinking, collaboration, cooperation, and control of computerized (Noermanzah \& Friantary, 2019). To that end, a good language learner is able to process language becomes an effective communication tool and persuasive as part of the ability of rhetoric in formal and informal situations (Noermanzah et al., 2018). Language is the most effective communication tool and is recognized as a human need in expressing their lives, because language is able to express joy, sadness, hope, and feelings that are characterized by the use of maxims that are politely valuable (Sayfryadin et al.,
2013 \& Noermanzah, 2017). This is in line with the opinion of Kosasih (2003) which states that with language we can express joy, sadness, hope, and other feelings. With language, those feelings can be easily understood by others. A person's language can reflect his thoughts. The more skilled a person is, the brighter and clearer his mind will be.

The use of language enables humans to communicate with each other, share experiences, and learn from each other. This is also in accordance with the opinion of Dardjowidjodjo (1996) who said that language has social power and can act as markers of identity, such as social identity, ethnic identity, or national identity, and national pride. 
Thus, in addition to being a communication tool, language also has social strength and is a means of thinking so that language can improve one's intellectual abilities. Chaer (2006) said language is a symbol system in the form of sound, used by a speech community to work together, communicate, and identify themselves. This opinion explains that language is used based on agreement. For this reason, why Indonesia has a wide diversity of languages because it not only consists of many islands but also has a diverse speech community in stating the sound symbol system.

Language learning involves four aspects including: listening, speaking, reading and writing. Specifically speaking is certainly more difficult than learning to understand the utterances of others, in other words speaking requires more energy and power of thought because it requires a strategy in processing information. The transfer of information, ideas, ideas, and opinions will go well if someone uses language that can be understood by others (Syafryadin et al., 2019).

For this reason, a person is required to have sufficient vocabulary mastery, because the more vocabulary is mastered, the more ideas and ideas he is able to express, both through speaking and writing activities (Noermanzah et al., 2019). Vice versa, if someone has a lot of ideas, but does not have a vocabulary of words to express it then it becomes useless. According to Tarigan (2008) speaking is a skill to convey messages through spoken language. This means that speaking is a language ability that requires skills, especially if speaking activities take place in front of many people. The activity of speaking in public is called public speaking.

Khayyirah (2013) said that public speaking or speaking in public is the art of public speaking about a matter verbally with the aim of influencing, inviting, educating, changing opinions, giving explanations, and providing information. However, still essentially public speaking is the ability to speak in public that requires skills. Public speaking is someone's skill in speaking that is not shared by everyone. This was revealed by Kriswanto in Khayyirah (2013) that the ability to speak in public is not owned by everyone, because this ability is closely related to personal image. Usually people who have this ability are often called leaders.

Speaking will greatly affect the listener what else if the speaking activity is carried out by a public figure, one of the speaking activities that is easily found is speeches. Speech is one type of public speaking, because speech is a speaking activity carried out by someone in front of the public in order to convey a certain goal (Yanuarita, 2012). Speech is included in the communication process, this communication can be said to be successful if the message delivered by the speaker can be received exactly the same as what is in the speaker's mind. However, communication is also influenced by factors that can reduce the smooth delivery of messages. This factor can be in the form of biological conditions such as speaker tools, psychological factors of the speaker, linguistic factors, and nonlinguistic factors such as social, situational, cultural factors, and language procedures. Speech is one type of human communication, used as a medium to convey someone's personal expression or use a unique style of expression.

The use of rhetoric in daily behavior such as in the context of speech will facilitate the efforts to foster rhetorical patterns. Expected convenience is in the context of fostering the ability to speak and write as a reflection of communication skills. Speech rhetoric which is used as a cultural tool if it is already owned and utilized by the wearer, is expected to help the development of culture itself, as well as to anticipate the emergence of miscommunication (Rachmat, 2015). It can be said that everyone who communicates and makes language a place for integrated behavior requires language rhetoric because language has the potential to form and succeed in understanding, so that it requires cultivation, and art in its delivery.

As a public figure, of course the speech delivered must be in accordance with the structure of a good speech so that the delivery of the contents of the speech can be easily accepted by the listener (Noermanzah, 2016). Therefore, the researcher chose to analyze the rhetorical structure of the Lubuklinggau Mayor's speech in building public trust. Aside from his position as a public figure, the Mayor of Lubuklinggau has his own attraction in rhetoric. This was revealed based on the researchers' initial observations of the Lubuklinggau City community, regarding the characteristics of the Mayor of Lubuklinggau in rhetoric including: (a) using language that is easily understood by the public / listener; (b) has lues body language; (c) often use local language so as to create a more intimate atmosphere, and (d) often interact with the listener so that the speech is not monotonous.

Speaking skills or rhetoric of speaking are also needed to achieve effective conversation in communication. It is undeniable that in the dynamics of life there are always differences that cause problems. As a speaker in formal situations such as in speeches, sermons, lectures, and others requires the processing of talks, not only in terms of linguistics, but also non-linguistic aspects such as fluency in speaking, attitudes, friendliness, mastery of the material, expression, expression, style, order or systematics, and 
mental involvement in speech. In addition, it also needs an understanding of the variations in rhetoric that are used when giving a speech, for example not only using variations of argumentation, but also mastering patterns of persuasion, narration, description, and exposition so as to create ethos, pathos, and logos (Noermanzah, 2017).

Language procedures or language rhetoric govern the use of language in communication systems. Hendrikus (2009) said that rhetoric is defined as the art of speaking well, which is used in the process of communication between people. Thus, rhetoric can be said as the art of speaking. Speaking means saying a series of words or sentences carried out by someone to achieve certain goals. Rhetoric can also be interpreted as a communication process, the process of a communicator delivering a message to the communicant.

This rhetoric theory was developed by Mann and Thompson (1987) which is derived from the narrative theory of texts, which is a way of organizing and describing texts naturally. The purpose of text analysis according to Mann and Thompson (1987) is to show how the structure of a text or discourse. This is in line with the opinion of Safnil (2010) who revealed that the RST views the notion of text as an organization. This theory seeks to describe the parts of the text that have a text and the principles used to combine parts of the text into a complete text. RST will certainly not explain all the structures that text might have.

Based on the RST theory, Labov developed a theory to analyze the generic structure of narrative texts (Safnil, 2010). In addition to analyzing the generic structure of the text, the researcher also analyzes how the structure is expressed in speech, how abstract disclosure, orientation, resolution, problem complexity, and code in the speech text so that it becomes whole paragraphs. The researcher uses a structural approach developed by Labov (in Safnil 2010) developing a generic structure of the text in five parts namely: 1) abstract is a brief statement about the story, basically the abstract naming here is intended to be a statement or general conclusion of the whole text. 2) Orientation is the determination of the time, place, and character of the story (a message for the reader to know). The orientation is actually the introduction or introduction to the core problem.

3) The complication of events is the main events that make events in the text occur or can be said to be statements of problems and supporting facts. This section serves to reveal the problems that occur and cause the need to get a solution. 4) Resolution related to how events in the text can be resolved, in addition to the resolution is also part of the text that contains problem solving, conclusions, suggestions, and attitudes of the author. This part can be said as the climax part in the text. Then, 5) koda, which is the bridge between the world of storytelling and the moment of storytelling, the koda also functions as the end or closing of the text. In closing, of course, the code contains sentences that end and contain an affirmation of the conclusion.

The issue of rhetoric needs to get the attention of educators, especially Indonesian language teachers and other language teachers, who develop students' speaking skills to express their ideas and thoughts, they are trained to utilize rhetoric in conversation, especially when conveying ideas and ideas in front of the forum. For that, speaking skills really need to be trained early to avoid the possibility of mistakes. Since speaking is a skill, effort and practice are needed to master it. The focus of the author's attention in this study is to answer How is the rhetorical structure of a speech so that the contents of the speech are effective and can be understood to the maximum by the listener? Given how important a learning material is, the researcher wants to imply the results of the analysis of the rhetoric structure of the Lubuklinggau Mayor's speech on speaking learning, especially in speech learning for high school students.

Mayor of Lubuklinggau Drs. H. SN Prana Putra Sohe, M.M. is one of the youngest mayors in Indonesia who has a character in persuading the public in each of his speeches so that he was re-elected as Lubuklinggau Mayor 2018-2023 who had previously served from 2013-2018. The persuasive style of rhetoric with a language that is populist and cares for the community is evidenced by its work program called Nansuko that can work well, for example the Development of Smart City, the Marase Program (Masjid Makmur Rakyat Sejahtera), and other programs that have been running in stages (Santoso et al ., 2019). This fact is consistent with the opinion of Shabani (2018), that persuasive steps greatly impact the running of a government program through speech activities. However, this persuasive style needs to be carried out a special study by examining how the rhetoric structure of the Mayor of Lubuklinggau's speech in building public trust, so that expectations become one of the teaching materials that can be used by educators in teaching speeches to their students and the development of speech rhetoric in Indonesia.

\section{RESEARCH METHODOLOGY}

The research method uses content analysis method with the help of generic narrative text structure and rhetorical structure theory. Data collection techniques using documentation techniques in the form of recorded speech by the Mayor of Lubuklinggau. The main instrument was the 
researcher in collecting data recording the speech of the Mayor of Lubuklinggau. This recording data was obtained from the Documentation Section of the Lubuklinggau Municipal Government.

The data that has been obtained is then transcribed and selected. The basis for selecting data refers to the characteristics of the netted text. For the purposes of this study, the selected texts include texts that are delivered naturally with the use of languages that are dominated by local languages. The data analysis technique uses a generic structure of narrative text and rhetorical structure theory with a pattern of content analysis carried out with the following steps:

1. Determination of material, the analysis begins with determining the material in the form of problems in research, namely the rhetoric structure of the Lubuklinggau Mayor's speech.

2. Analysis of the situation where the text originated, describes the social conditions or social background of the speech text of the Mayor of Lubuklinggau.

3. Formality of material.

4. Determination of the direction of the analysis, determine the parts of the speech structure based on rhetorical structure theory, namely abstract, orientation, complication of events, resolution, and codes.

5. Differentiation of the questions that must be answered in accordance with existing theories, adjust whether the structure of speech in accordance with the theory consisting of abstracts, orientation, complication of events, resolution, and code.

6. Selection of analytical techniques (summary, application, arrangement).

7. Defining units of analysis, defining each part of the structure of speech.

8. Analysis of material (summary, application, arrangement).

9. Interpretation, is the interpretation or meaning of the text content of each rhetorical structure found, starting from the abstract, orientation, complication of events, resolution, and code.

10. Implications of the results of the analysis in learning to speak specifically speech learning (Mayring in Titscher, 2009).

Test the validity of the data using member checking techniques and validation test from the expert in speech discourse analysis. Then, the credibility is by making transcripts of Lubuklinggau Mayor's recorded speech in written text.

\section{FINDINGS AND DISCUSSION}

\section{A. Findings}

The speech rhetoric structure of the Mayor of Libuklinggau was analyzed from four speech texts which were chosen based on the delivery characteristics. Following are the results of the speech rhetoric structure of the Mayor of Lubuklinggau City.

Table 1. Structural Rhetoric of the Mayor of Lubuklinggau

\begin{tabular}{|c|l|c|c|c|c|c|}
\hline \multirow{2}{*}{ Nu. } & \multirow{2}{*}{$\begin{array}{c}\text { Speech Text } \\
\text { Code }\end{array}$} & \multicolumn{5}{|c|}{ Generic Text Structure } \\
\cline { 3 - 7 } & & Abstract & Orientation & Complication & Resolution & Koda \\
\hline 1. & STK1 & $\sqrt{ }$ & $\sqrt{ }$ & $\sqrt{ }$ & $\sqrt{ }$ & $\sqrt{ }$ \\
\hline 2. & STK2 & - & $\sqrt{ }$ & $\sqrt{ }$ & $\sqrt{ }$ & $\sqrt{ }$ \\
\hline 3. & BBGRM & $\sqrt{ }$ & $\sqrt{ }$ & $\sqrt{ }$ & $\sqrt{ }$ & $\sqrt{ }$ \\
\hline 4. & PPL & $\sqrt{ }$ & $\sqrt{ }$ & $\sqrt{ }$ & $\sqrt{ }$ \\
\hline
\end{tabular}

From the tabulated data above, it can be explained that in general all Libuklinggau Mayor speech texts reveal the analysis of generic text structures in the form of abstracts, orientations, event complexities, resolutions, and codes. Only the STK2 text has no abstract sections.

\section{STK Speech Rhetoric Structure}

While the results of the structural analysis of each speech can be seen in the following table. 
Table 2. Tabulation of Text Data for STK Speeches

\begin{tabular}{|c|l|l|l|l|}
\hline Nu. & \multicolumn{1}{|c|}{ Title of Text } & \multicolumn{1}{|c|}{ Structure } & Paragraph & \multicolumn{1}{c|}{ Interpretation } \\
\hline 1. & $\begin{array}{l}\text { One Year Lubuklinggau } \\
\text { City Leadership Position } \\
\text { (STK1), (STK2) }\end{array}$ & $\begin{array}{l}\text { Abstract } \\
\text { Orientation } \\
\text { Complication } \\
\text { Resolution }\end{array}$ & $\begin{array}{l}4,10 \\
1,2 \text { and } 9\end{array}$ & $\begin{array}{l}\text { The text has a complete and dual } \\
\text { structure so that there are 2 parts of } \\
\text { orientation, 2 parts of complexity, } 2 \\
\text { parts of resolution and 2 parts of code. } \\
\text { In the STK2 text, it has no abstract } \\
\text { parts. This doubling is because there is a } \\
\text { second person greeting in a speech that } \\
\text { has not yet been closed. }\end{array}$ \\
\hline Koda & $11,6,8$ and 13 & \\
\hline
\end{tabular}

The STK speech consists of 13 paragraphs and has a double structure, so that the structure of the speech text is divided into two, namely the structure of STK1 and STK2. In general, the structure contained in the STK speech is in accordance with the theory, which consists of abstract, oreantasi, complicated, resolution, and koda sections. It's just that the abstract part is not found in the STK2 text structure, what is meant by a double structure is that in this STK text the speech is delivered by two different people so that in one text it has a different structure. The structure difference is in the abstract part where STK1 has an abstract and vice versa the STK2 part does not have an abstract. In STK1, in general if the abstract part is found in paragraph 3, the orientation part is in paragraphs 1 and 2, the complicated part is in paragraph 4 , the resolution section is longer and in paragraphs 5, 6, 7 and 8 , then the code is in paragraph 13 . Whereas STK 2 does not have an abstract section beginning directly with the orientation section contained in paragraph 9 , the complication section is in paragraph 10 , the resolution section is in paragraph 11, and the code is in paragraph 12 .

\section{Structure of BBGRM Speech Rhetoric}

Table 3. Tabulation of BBGRM Speech Text Data

\begin{tabular}{|c|c|c|c|c|}
\hline $\mathrm{Nu}$. & Title of Text & Structure & Paragraph & Interpretation \\
\hline 1. & $\begin{array}{l}\text { Opening of BBGRM } \\
\text { in Lubuklinggau } \\
\text { City (BBGRM) }\end{array}$ & $\begin{array}{l}\text { Abstract } \\
\text { Orientation } \\
\text { Complication } \\
\text { Resolution } \\
\text { Koda }\end{array}$ & $\begin{array}{l}3 \\
1,2, \\
4,5,6 \\
7,8,9 \\
10\end{array}$ & $\begin{array}{l}\text { This text has a complete structure with } \\
\text { disclosure of complicated parts and } \\
\text { resolutions that are almost the same } \\
\text { length. }\end{array}$ \\
\hline
\end{tabular}

The BBGRM text consists of 10 paragraphs and has a complete structure in accordance with the theory, which has an abstract, orientation, complexity, resolution and code section. the abstract section is in paragraph 3, the orientation section is in paragraphs 1 and 2, the complication section is in paragraphs 4, 5 and 6, the resolution section is in paragraphs 7,8, and 9, while the code is in paragraph 10 . Based on these details then it can be seen that the complicated part is delivered long enough so that it is almost the same length as the disclosure of the resolution. 


\section{Structure of PPL Speech Rhetoric}

Table 4. Tabulation of PPL Speech Text Data

\begin{tabular}{|c|c|c|c|c|}
\hline $\mathrm{Nu}$. & Title of Text & Structure & Paragraph & Interpretation \\
\hline 1. & $\begin{array}{l}\text { Inauguration of the City of } \\
\text { Lubuklinggau Paskibra } \\
\text { (PPL) }\end{array}$ & $\begin{array}{l}\text { Abstract } \\
\text { Orientation } \\
\text { Complication } \\
\text { Resolution } \\
\text { Koda }\end{array}$ & $\begin{array}{l}2 \\
1 \\
3,4,5,6 \\
7,8,9 \\
10\end{array}$ & $\begin{array}{l}\text { This text has a complete structure } \\
\text { with a fairly long section of } \\
\text { complexity. }\end{array}$ \\
\hline
\end{tabular}

PPL text consists of 10 paragraphs and has a complete structural part in accordance with the theory that consists of abstract, orientation, complicated resolution, and code sections. Based on the table above, it can be explained that the abstract part is in paragraph 2, the orientation part is in paragraph 1 , the complicated part is in paragraphs $3,4,5,6$ then the resolution part is in paragraphs 7, 8, 9 while the code is in paragraph 10. Based on the table above it can be seen that the PPL text has a complicated part that is longer than the rest of the structure.

\section{B. Discussion}

Overall speech by the Mayor of Lubuklinggau has a structure that is in accordance with the generic structure of the Labov text that consists of abstracts, orientation, complication of events, resolution, and data and fact-based codes in persuading the community (Thompson, 1987; Safnil, 2010). This was represented by three speeches by the Mayor of Lubuklinggau with the STK, BBGRM, and PPL codes. These three speeches were selected by selection based on the delivery of speeches without using text so that the use of the language truly reflects the personality of a Mayor of Lubuklingau.

The STK speech text is a speech consisting of 13 paragraphs, and the only text with a double structure, this is because in the middle of the speech, the Mayor asks someone to continue the conversation by inviting Mr. Dodi Alex Noerdin to give a little speech and then the Mayor resumed the conversation by conveying hopes, conclusions and closing his remarks. As such, there is a dual structure that must be analyzed in this text. The text was delivered with the dominance of the Palembang regional language, in the delivery of this speech it was preceded by small talk with a touch of humor that had meaning asking for an announcement to attendees about the event that did not provide consumption of this matter contained in paragraph 1 . In this text the Mayor of Lubuklinggau seeks to socialize his efforts in improving the City of Lubuklinggau. This socialization effort was evident by the way he revealed the program that had been implemented and how the process to be able to implement these efforts. By presenting Mr. Dodi Alex Noerdin in the middle of the discussion it certainly has a certain purpose because Mr. Dodi Alex Noerdin is a 2014 DPR RI Candidate. By disclosing his services to the City of Lubuklinggau will certainly get the sympathy of the people of the City of Lubuklinggau. Especially since the beginning, he always mentioned the name of Bung Dodi at the end of his sentence. Even though there were many attendees who could have actually been mentioned to get attention, but the mayor tends to mention the name Bung Dodi. This tendency is found in the 2nd paragraph, 4th paragraph, 5th paragraph, 6th paragraph, 7th paragraph, and 8th paragraph continues until the peak Mr. Mayor invites Mr. Dodi to continue his conversation. The remarks from Mr. Dodi consisted of 4 paragraphs which had an orientation, complexity, resolution, and code structure. There was no abstract in his remarks, and what he conveyed was in the form of his interesting experiences with the Mayor some time ago so as to convince him that Lubuklinggau will be Better in the future. On the other hand also expressed hopes and prayers that imply meaning to ask for community support so that good relations are maintained so that he who will step as an official of the Republic of Indonesia will be able to support the development of the City of Lubuklinggau. This is found in paragraph 12. In general each paragraph has unity and cohesiveness between the sentences so as to provide understanding to the community (Halliday and Hasan, 1976).

The BBGRM speech text has a complete structure as it should, namely having an abstract part, orientation, complication of events, and koda. This text consists of 10 
paragraphs, this text has similarities with the STK text in the orientation section, in the 1st paragraph, the Mayor welcomes the audience with pleasantries, but this time has the meaning of respect to the Governor of South Sumatra who had the opportunity to attend. Broadly speaking, this speech was delivered in the regional language of Palembang. In the second paragraph only contains respect and praise to the Governor of South Sumatra regarding his success in developing the Province of South Sumatra. This speech was actually aimed at conveying information to the public regarding the assistance of the Governor to the City of Lubuklinggau by distributing funds of 100 million in each village. In addition, he also expressed his gratitude to 39 residents of Temam Kelurahan who were willing to give their land to build a pivot road from Temam to Lubuk Kupang, this is contained in paragraph 3. However, this discussion shifted to a report to the governor regarding the 1 year leadership period of the mayor and deputy mayor in Lubuklinggau, so that what was delivered was the same as what was delivered in the text of the STK speech, namely the disclosure of government efforts to build the City of Lubuklinggau. This is contained in paragraph 6 , paragraph 7 , paragraph 8 and paragraph 9. This speech ended with great hopes that development in the City of Lubuklinggau will not only be a source of pride for the city community, but also the people of the province.

PPL text consists of 10 paragraphs and has a complete structure that is the abstract part, orientation, complication of events, resolution and codes. This text does not begin with small talk that contains humorous elements, but directly greeting, this is because the event took place more officially. This speech was delivered with the aim of confirming or inaugurating members of the Lubukinggau City Paskibra in 2014. This speech conveyed more gratitude, hope, advice and congratulations to selected Paskibra members. The message left is how the flag-raising task can run successfully so that there is great hope not to underestimate this task and must really try to protect yourself with health that is affected by diet and daily activities, this is conveyed in paragraph 6 and paragraph 7 th. In this text information is also conveyed that the implementation of the ceremony is not as usual, the independence ceremony which is usually held at Merdeka Square now has to change history to be carried out at the Kayu Kayu Field because the Great Mosque has been built which makes Merdeka Square a mosque garden.

This submission is actually an expression of the mayor's apology to the people to change history with the aim of building the City of Lubuklinggau for the better. In the middle of the conversation, he expressed his pride towards the PKK Choir Team who had accompanied the event so that it felt more solemn. This delivery is none other than because at this time the PKK Choir Team is enough to attract attention with some proud achievements, this is contained in the 8th paragraph. To increase the enthusiasm of Paskibra members on duty, he promised to invite selected Paskibra members to take an insight tour to neighboring countries if the task can be completed successfully, this is stated in paragraph 9. The speech ended with official congratulations and official confirmation words.

The advantages of the Lubuklunggu Mayor's speech, each rhetorical structure that was presented starting from the abstract, orientation, complication of events, resolution, and koda had an element of persuasion supported by facts and data as well as giving awards to the participants present. These facts and data are part of the ability in rhetoric called logos, which is logical evidence or the use of arguments and evidence in a speech. This logos will also lead to ethos that is the credibility of a mayor. Then, the use of the ability of phatos to always say thank you and apologize by using the national language and the language of the Lubuklinggau region so that it creates a feeling of mutual intimacy and belonging to the City of Lubuklinggau. This ethos, pathos, and logos presentation strategy is able to provide its own motivation to the community and will generate trust in the government (Altikriti, 2016; Noermanzah, 2017).

\section{CONCLUSION ANd Suggestion}

Speech of the Mayor of Lubuklinggau has a structure in accordance with the generic structure of the Labov text that consists of abstracts, orientation, complication of events, resolutions, and codes based on data and facts in persuading the community so as to create a sense of mutual ownership between the government and the community. Then, specifically, there are some rhetorical structures used by the Mayor of Lubuklinggau in his speech, as follows.

1. Has an abstract structure, orientation, complexity of events, resolution, and code.

2. Each text has a structure that tends to be the same except that the STK text has a double structure so that it has a difference with BBGRM text and PPL text.

3. The content of course every speech has a different topic it's just that there are always characteristics that are owned namely:

a. Submission is dominated by regional languages namely Palembang.

b. Beginning with small talk that implies a specific purpose and is accompanied by expressions that contain humor. 
Some suggestions from the results of this study, namely for further research, research should be done in a longer time so that the acquisition of data can be obtained to the maximum, understanding will be deeper by making comparisons to speeches of other officials in the City of Lubuklinggau. Then, for speech learning, the results of this analysis can be used as speech learning material and can improve student understanding in analyzing the structure of speech texts.

\section{REFERENCES}

[1] Altikriti, S. 2016. Persuasive Speech Acts in Barack Obama's Inaugural Speeches $(2009,2013)$ and The Last State of the Union Address (2016). International Journal of Linguistics, $8(2)$.

[2] Chaer, A. 2006. Tata Bahasa Praktis Bahasa Indonesia. Jakarta: PT Rineka Cipta.

[3] Dardjowidjodjo, S. 1996. Bahasa Nasional Kita. Bandung: ITB.

[4] Halliday, M.A.K. dan Ruqaiya Hasan. 1976. Cohesion in English. London: Longman.

[5] Hendrikus, D. W. 2009. Retorika: Terampil Berpidato, Berdiskusi, Berargumentasi, Bernegoisasi. Yogyakarta: Kanisius.

[6] Khayyirah, B. 2013. Cara Pintar Berbicara Cerdas di Depan Publik. Yogyakarta: Diva Press.

[7] Kosasih, E. 2003. Ketatabahasaan dan Kesusastraan. Bandung: Yrama Widya.

[8] Mann, W. C. \& Thompson, Sandra A. 1987. Rhetorical Structure Theory: A Theory of Text Organization. Washington: National Science Foundation (NSF).

[9] Noermanzah \& Friantary, H. 2019. Development of Competency-Based Poetry Learning Materials for Class $\mathrm{X}$ High Schools. International Journal of Recent Technology and Engineering, 8(4), 6631.

[10] Noermanzah, Emzir, \& Lustyantie, N. 2018. President Joko Widodo's Rhetorical Technique of Arguing in the Presidential Speeches of the Reform Era. International Journal of Applied Linguistics and English Literature, 7(5), 118. doi:10.7575/aiac.ijalel.v.7n.5p.117

[11] Noermanzah, Hermanudin, Suhartono, \& Suryadi. 2019. Improvement of Reading Comprehension Ability by Using Core Models of Class VII a Students of SMP Negeri 10 Bengkulu Tengah. International Journal of Scientific and Technology Research, 8(12).
http://www.ijstr.org/paper-references.php?ref=IJSTR1219-25902

[12] Noermanzah, N. 2016. Sermon Rhetoric Patterns of President Joko Widodo's Oration in the Occasion of Bung Karno's Oration on June 1, 1945 Commemoration. Journal of Indonesian Language Education and Literary, 1(2), 10 .

[13] Noermanzah, N. 2017. Rhetorical Devices in the Presidential Speeches of the President of the Republic of Indonesia in the Reformation Era. KnE Social Sciences, 3(9), 435-445. https://doi.org/10.18502/kss.v3i9.2705

[14] Noermanzah, N., Emzir, E., \& Lustyantie, N. 2017. Variety of Rhetorics in Political Speech President of the Republic of Indonesia Susilo Bambang Yudhoyono and Joko Widodo in Educational Field. Humanus: Jurnal Ilmiah Ilmu-ilmu Humaniora, 16(2), 221. doi:10.24036/humanus.v16i2.8103

[15]Rakhmat, J. 2015. Retorika Modern: Pendekatan Praktis. Bandung: PT Remaja Rosdakarya.

[16] Safnil. 2010. Pengantar Analisis Retorika Teks. Bengkulu: FKIP UNIB.

[17] Santoso, et al. 2019. Banyak Tantangan Dihadapi. https://www.linggaupos.co.id/banyak-tantangandihadapi/

[18] Shabani, S. 2018. Persuasive Strategies Towards Racial Appeal in Tony Morrison's the Bluest Eye. International Journal of Applied Linguistics and English Literature (IJALEL), $7(1)$, http://dx.doi.org/10.7575/aiac.ijalel.v.7n.1p.19.

[19] Syafryadin, Haryani, Salniwati, \& Putri, A. R. A. 2019. Digital Storytelling Implementation for Enhancing Students' Speaking Ability in Various Text Genres. International Journal of Recent Technology and Engineering (IJRTE), 8(4), 3147-3151.

[20] Syafryadin, Rahmawati, I. N., \& Widiastuti, R. 2013. Improving grade X Students' Speaking Achievement under Round Robin Technique. International Journal on Education, 1(1).

[21] Tarigan, H. G. 2008. Berbicara sebagai Suatu Keterampilan Berbahasa. Bandung: Angkasa.

[22] Titscher, S. et al. 2009. Methods of Text and Discourse Analysis. Dalam Ibrahim, Abdul Syukur (ed). Metode Analisis Teks dan Wacana. Yogyakarta: Pustaka Belajar. 
[23] Yanuarita, A. 2012. Langkah Cerdas Mempersiapkan

Pidato dan MC. Yogyakarta: Teranova Books. 